\title{
Coping with hunger? Visions of a global food system, 1930-1960
}

\author{
Ruth Jachertz \\ Berlin, Germany \\ E-mail: Ruth.Jachertz@gmx.de \\ Alexander Nützenadel \\ E-mail: nuetzenadel@geschichte.hu-berlin.de
}

Institut für Geschichtswissenschaften, Humboldt-Universität, Unter den Linden 6, D-10099

\begin{abstract}
The 1930s and 1940s saw the rise of a new model of global food politics. This model was strongly moulded by the experiences of the Great Depression and the two world wars, all of which had brought hunger and malnutrition back to Europe. Whereas until the nineteenth century famines and food shortages had commonly been interpreted as regional Malthusian crises, they were now attributed to global economic disturbances and imbalances. This article explores how the far-reaching plans of a World Food Board, advocated by the UN Food and Agriculture Organization under John Boyd Orr, were abandoned and supplanted by a new approach that focused on technical aid and the distribution of surpluses. Moreover, the problems of hunger and malnutrition were embedded in a larger discourse on world population and economic development.
\end{abstract}

Keywords agriculture, food, Food and Agriculture Organization, hunger, inequality

In 1962, the German politician and agricultural scientist Fritz Baade published a book entitled The race to the year 2000. Our future: a paradise or the suicide of mankind. ${ }^{1}$ This groundbreaking work, which was published in twenty editions and translated into numerous languages, was not only one of the most successful non-fiction books of the post-war era but also represented a specific kind of global analysis that combined historical perspectives with predictions for the future. The present challenges to humankind - extensive population growth, scarcity of resources, destruction of the global environment, and hunger crises of the 'Third World' - were, according to Baade, the result of long-term global transformations that had their origins in the era of the world wars and whose threats could only be diverted through rapid international action.

Indeed, even though the post-war era was faced with a sequence of severe famines in Asia and Africa, Baade's vision of the global food system was not entirely pessimistic. He strongly believed that, with the establishment of a powerful world government, economic growth and social progress would rapidly spread across borders, eliminating poverty and hunger throughout the world. Baade's optimism towards international cooperation was

1 Garden City: Doubleday, 1962. 
not only shared by many of his contemporaries but has also inspired more recent trends in both political sciences and historical research. ${ }^{2}$ It has been argued that the number of international organizations, agreements, and regulations has constantly risen in the decades since $1945 .^{3}$ While globalization has challenged the political power of sovereign states, transnational institutions and politics have gained significantly in importance. Most historians and political scientists agree that, by intensifying international cooperation, fundamental problems of the global community can be resolved. ${ }^{4}$

Surprisingly, the vast literature on the emergence of international regimes and global governance has almost completely ignored the food sector. ${ }^{5}$ While there are studies on topics such as the United Nations or the Bretton Woods monetary system, little attention has been paid to international food policy during the post-war era. ${ }^{6}$ This is unexpected, given the central role that the food sector played in the global economy during this period. Moreover, numerous regions were confronted with food shortages and famines after 1945, while overproduction in North America and western Europe led to new forms of regional protectionism and market organization. With decolonization and the appearance of independent nation-states in Asia and Africa, food trade became a highly politicized issue of the newly emerging North-South conflict. The right to food moved to the centre of international debates on human and social rights. As a consequence, hunger and malnutrition were seen as the most fundamental expressions of global inequality, triggering new programmes of international humanitarian intervention and development aid.

At the same time, however, the food sector was one of the most intransigent areas of international regulation, as advocates of a global food policy would soon realize.

2 Vincent Cable, Globalization and global governance, London: Pinter, 1999; Michael Barnett and Martha Finnemore, Rules for the world: international organizations in global politics, Ithaca, NY: Cornell University Press, 2004.

3 Michael Wallace and David J. Singer, 'Intergovernmental organization in the global system, 1815-1964: a quantitative description', International Organization, 24, 1970, pp. 239-87; Craig N. Murphy, International organization and industrial change: global governance since 1850, Cambridge: Polity Press, 1994; Akira Iriye, Global community: the role of international organization in the making of the contemporary world, Berkeley, CA: University of California Press, 2002.

4 Kenichi Ohmae, The end of the nation state: the rise of regional economies, New York: Free Press, 1995; Stephen D. Krasner, ed., Problematic sovereignty: contested rules and political possibilities, New York: Columbia University Press, 2000.

5 Important for the early history of the UN Food and Agriculture Organization (FAO): Amy L. S. Staples, The birth of development: how the World Bank, Food and Agriculture Organization, and World Health Organization changed the world, 1945-1965, Kent, OH: Kent State University Press, 2006, pp. 64-122; see also D. John Shaw, World food security: a history since 1945, Basingstoke: Palgrave Macmillan, 2007.

6 Barry Eichengreen, Globalizing capital: a history of the international monetary system, Princeton, NJ: Princeton University Press, 1996; Michael D. Bordo and Barry Eichengreen, eds., A retrospective on the Bretton Woods system: lessons for international monetary reform, Chicago: University of Chicago Press, 1997; Paul Kennedy, The parliament of man: the United Nations and the quest for world government, London: Penguin Press, 2006; John Toye and Richard Toye, The UN and global political economy: trade, finance, and development, Bloomington, IN: Indiana University Press, 2004; Yves Berthelot, ed., Unity and diversity in development ideas: perspectives from the UN regional commissions, Bloomington, IN: Indiana University Press, 2004; Louis Emmeriji, Richard Jolly, and Thomas G. Weiss, Ahead of the curve? UN ideas and global challenges, Bloomington, IN: Indiana University Press 2001; Richard Jolly, Louis Emmerij, Dharam Ghai, and Frédéric Lapeyre, UN contributions to development thinking and practice, Bloomington, IN: Indiana University Press, 2004; Craig N. Murphy, The United Nations Development Programme: a better way?, Cambridge: Cambridge University Press, 2006. 
Scientists participating in the discussions leading to the creation of the Food and Agriculture Organization (FAO) had high expectations that this new UN organization would fulfil the plans of the League of Nations for a global food policy based on the nutritional needs of consumers. Allied cooperation in food allocation, international humanitarian aid, and new scientific discoveries about nutrition all supported a global view of a world food system. Yet wartime experience also strengthened the quest for autarky or, at least, national control over access to food. These conflicting tendencies between, on the one hand, the need for cooperation to ensure global food security and, on the other, the desire for national or at least regional control over food supplies continued to shape food policy in the coming decades. The ultimate failure of the FAO's visions of global food distribution reveals the limits of cooperation in the food sector. It also questions the assumption that global governance has persistently increased since 1945 .

This article consists of three sections. In broad strokes, the first section explains how the experiences of the world wars placed questions of food security high up on the political agenda. The FAO's vision of a global food system and the reasons for its ultimate failure form the second part. The third part examines how, during the 1950s, the FAO abandoned the idea of global market regulation and moved its activities towards short-term food aid and technical assistance. Furthermore, the global food problem was now embedded in a larger discourse on world population and economic development.

\section{Hunger experience and food cooperation in the era of the world wars}

The era of the world wars is commonly viewed as the end of the first great wave of globalization, which had peaked in the second half of the nineteenth century. In fact, the First World War not only caused the collapse of the international system but also brought a long period of liberal trade policy to a close. ${ }^{7}$ At the same time, however, the war reinforced the awareness of global interdependence in the production, distribution, and consumption of food resources. It had made Europeans painfully aware of how much they were dependent on food imports from overseas, and the ability to organize international markets was a key factor in bringing about the victory of the Allied Forces. ${ }^{8}$ Enormous bureaucratic organizations and rationing systems were established to handle the growing problems in the supply and distribution of staple foods. Decreased production in the war-ravaged areas of Europe and the loss of Russia as an exporter of grains induced an enormous demand for agricultural exports from overseas. Countries already producing surpluses, such as the United States, Canada, Argentina, and Australia, were able to increase production and bolster their hold on European markets.

7 Gerd Hardach, The First World War 1914-1918, London: Allen, 1977; Michael Tracy, Government and agriculture in Western Europe, 1880-1988, New York: New York University Press, 1988, pp. 119-211; Alexander Nützenadel, 'A green international? Food markets and transnational politics (1850-1914)', in Alexander Nützenadel and Frank Trentmann, eds., Food and globalization: consumption, markets and politics in the modern world, Oxford: Berg Publishers, 2008, pp. 153-73.

8 C. Paul Vincent, The politics of hunger: the Allied blockade of Germany, 1915-1919, Athens, OH: Ohio University Press, 1985; Avner Offer, The First World War: an agrarian interpretation, Oxford:

Clarendon, 1989. 
As a consequence of the First World War, gaining access to food resources became a geopolitical task of foremost importance. Even though European agriculture recovered rapidly after the cease of war, the question of food security remained on the political agenda in many countries. From the mid 1920s, market and trade regulation were amplified in most countries around the world. Especially in Europe, import tariffs and subsidies were introduced in order to combat falling prices and worsening terms of trades. However, this was not merely a return to the classic protectionist stance of the nineteenth century. More than simply an attempt to avert the consequences of the international downturn in prices, the increased regulation of markets was also a means to secure long-term food provisions within a destabilized international environment. This idea was radicalized under Fascist and other authoritarian regimes that aimed to establish economic autarchy and geopolitical hegemony. ${ }^{9}$ However, other countries also witnessed a renaissance of Malthusian theories addressing the relations between population growth and food resources.

At the same time, the 1920s saw the birth of international food assistance, with the First World War having an almost catalytic effect in this regard as well. ${ }^{10}$ Since then, the provision of food has been framed as a political problem that presents national governments with new challenges, yet also proves resistant to the classic remedies of the nation-state. American and European foundations such as the Commonwealth Fund, the Deutsche Hungerhilfe, and the Rockefeller Foundation moved the problems of international food and health policies to the centre of their activities. The massive hunger crises in post-revolutionary Russia, which took the lives of more than five million, set off a wave of international solidarity. ${ }^{11}$ Relief operations were often coordinated by the same men who had planned the distribution of food and resources during war times. These men included Herbert Hoover, who since 1920 had chaired the American Relief Association, Fridtjof Nansen, the Norwegian refugee commissioner, and Walther Rathenau, the former head of the German Department of Economic Resources, who initiated the international aid programmes for Russia and eastern Europe.

Against this background, hunger was no longer seen solely as a symptom of regional crises but became an expression of global imbalances; it began to be viewed as a problem that was not going to be solved without some form of international regulation. In an address to the League of Nations in October 1921, Nansen declared: 'Argentina is burning its grain surplus; America is letting its corn rot in its silos; Canada has more than two billion tons of leftover grain - and yet, in Russia, millions are dying of hunger. ${ }^{12}$

9 See Gustavo Corni, Hitler and the peasants: agrarian policy of the Third Reich, 1930-1939, New York: Berg, 1990; Christian Gerlach, Krieg, Ernährung, Völkermord: Forschungen zur deutschen Vernichtungspolitik im Zweiten Weltkrieg, Hamburg: Hamburger Edition, 1998; Alexander Nützenadel, Landwirtschaft, Staat und Autarkie: Agrarpolitik im faschistischen Italien 1922-1943, Tübingen: Niemeyer, 1997.

10 See John Burnett and Derek J. Oddy, eds., The origins and development of food policies in Europe, London: Leicester University Press, 1994; Frank Trentmann, 'Coping with shortage: the problem of food security and global visions of coordination, c. 1890s-1950', in Frank Trentmann and Flemming Just, eds., Food and conflict in Europe in the age of the two world wars, Basingstoke: Palgrave Macmillan, 2006, pp. 13-48.

11 Bertrand M. Patenaude, The big show in Bololand: the American relief expedition to Soviet Russia in the famine of 1921, Stanford, CA: Stanford University Press, 2002.

12 Cited in Wolfgang Eckart, 'Nach bestem Vermögen tatkräftige Hilfe leisten: die Deutsche Hungerhilfe Vorhaben und Wirkungen', Ruperto Carola, 3, 1999, p. 16. 
These global perspectives also shaped the debates concerning a reform of the international agricultural markets initiated by the League of Nations during the Great Depression. The overarching goal was not to divert the negative consequences of the crisis from farmers but to establish an international system that would guarantee the global supply of food commodities. ${ }^{13}$ In other words: the producer's perspective, which had long dominated agricultural policy, was now being complemented by a stronger orientation towards the interests of consumers. Representatives of the League of Nations as well as the International Labour Organization (ILO) therefore vigorously combated the increasing protection of domestic markets, the costs for which were born by consumers. ${ }^{14}$ The plans of Arthur Salter, head of the Economic Department of the League of Nations, extended even further. He proposed the institution of an International Food Board, which would prevent price fluctuations on world markets through the purchase and sale of food commodities and would balance regional deficits in distribution via prompt aid shipments. ${ }^{15}$

It was quite obvious that such an intervention required not only powerful institutions but also comprehensive data and prognoses concerning the development of markets. From the 1920s onwards, the International Institute of Agriculture (IIA) in Rome had been releasing international agricultural statistics, which not only listed each country's harvest but also documented the relations between production, trade, and consumption on a global scale. From 1930, these statistics also included nutritional data. ${ }^{16}$

It has often been argued that the IIA and other bodies such as the ILO were mainly engaged in economic studies and statistical surveys, while their political impact was quite limited. This interpretation ignores the fact that scientific experts played an important role in the discourse on global reform. The notion that scientific knowledge and economic expertise could contribute to the resolution of global problems gained strong support during the interwar period. This was also true for the newly created think tanks and private foundations in the United States and Great Britain that engaged in campaigns against famines and food shortages. Raymond Fosdick, who, as president of the Rockefeller Foundation after 1936, led what might well have been the most influential foundation in the world at the time, regarded empirical knowledge as the most important resource for the reform of the global economic system. 'Through modern statistics we are able, in our generation, to get a complete picture of supply and demand in relation to the world's food', he declared in 1931. 'The field has been surveyed and the factors are known. What we need now is synthetic thinking, constructive brains, and a plan, laid down in world terms. ${ }^{17}$

While the Rockefeller Foundation was far from any 'plan laid down in world terms', it successfully initiated agricultural and developmental projects in China and supported

13 See for example, League of Nations, Economic Committee, The agricultural crisis, Geneva: League of Nations, 1931.

14 Francois Houillier, L'organisation internationale de l'agriculture: les institutions agricoles internationales et l'action internationale en agriculture, Paris: Librairie Technique et Économique, 1935, pp. 290-1.

15 Trentmann, 'Coping with shortage', pp. 28-9.

16 International Institute for Agriculture, The first world agricultural census (1930): a methodological study on the questions contained in the forms adopted for the purposes of census in the various countries, Rome: International Institute for Agriculture, 1937.

17 Raymond Blaine Fosdick, The old savage in the new civilization, Garden City: Doubleday, Doran \& Company, 1931, pp. 179-80. 
medical research on yellow fever and malaria in Africa in the 1930s. Furthermore, the Foundation supported a large research programme on plant genetics, carried out in Mexico in 1944 by the later Nobel Prize laureate Norman Borlaug. ${ }^{18}$ The aim of this research was to overcome the food challenges of Central and South America by breeding high-yield varieties of grain. Such initiatives were groundbreaking because they anticipated the amalgamation of food policy, the transfer of technology, and the development that would characterize many programmes towards the 'Third World' after 1945 . $^{19}$

During the 1930s, a more integrated view of food and food research gained ground and sparked new inquiry at the intersection of medicine, agricultural science, and economics. ${ }^{20}$ On the one hand, dietary research explored how many fats, proteins, carbohydrates, iron compounds, vitamins, and trace elements were required to maintain basic bodily functions. In 1941, the American Food and Nutrition Board created its Recommended Dietary Allowances (RDA), which soon became an international reference system for dietary standards. While the standards were originally developed for the armed forces and civilians during the Second World War, they were also used for calculating food relief for the overseas population. On the other hand, the 'science of hunger' established itself as a new field of medical and nutritional research. While European clinicians had already discovered instances of hunger and starvation in the colonies in the late nineteenth century, they were now able to study symptoms at their own front door. As entire European regions - in particular, Greece, the Netherlands, and vast parts of eastern Europe - were exposed to massive hunger, doctors in occupied cities, camps, and asylums found thousands of cases to study the medical pathologies of starvation. ${ }^{21}$

Finally, there was a new strand of research on income, living standards, and nutrition, which harked back to the Great Depression of the early 1930s. In 1936, John Boyd Orr, a British physiologist who was to become the first Director-General of the FAO, published his groundbreaking study Food, health and income, which provided the foundation for a social approach to nutrition. ${ }^{22}$ Based on extensive empirical research, he concluded that only about half of all British families were able to feed themselves properly, and that more than a third of the population was malnourished. These findings were confirmed by the Mixed Committee on Nutrition that was established by the League of Nations in 1935. In its Final report on the relation of nutrition to health, agriculture and economic pol$i c y$, it provided a detailed picture of malnutrition and hunger in different parts of the world. As the committee argued, rather than the product of natural disasters, hunger was the result of the failure of the industrialized nations 'to adapt our economic policies and distributive

18 Deborah Fitzgerald, 'Exporting American agriculture: the Rockefeller Foundation in Mexico, 19431953', Social Studies of Science, 16, 1986, pp. 457-83; Marcos Cueto, ed., Missionaries of science: the Rockefeller Foundation and Latin America, Bloomington, IN: Indiana University Press, 1994.

19 Nick Cullather, 'Miracles of modernization: the Green Revolution and the apotheosis of technology', Diplomatic History, 28, 2, 2004, pp. 227-54.

20 Staples, Birth of development, pp. 64-74; see also Nick Cullather, 'The foreign policy of the calorie', American Historical Review, 112, 2007, pp. 337-64.

21 Dana Simmons, 'Starvation science: from colonies to metropole', in Nützenadel and Trentmann, Food and globalization, pp. 173-91.

22 John Boyd Orr, Food, health and income: report on a survey of diet in relation to income, London: Macmillan, 1936. 
systems to the increased production of wealth which progress in the scientific field had made available'. 23

Even though fighting malnutrition and hunger were the main goals of international food programmes, they were also expected to boost general economic development on a global scale. Studies of the League of Nations conducted during the Great Depression had repeatedly referred to the specific problems of agriculture and their devastating consequences for the world economy. ${ }^{24}$ Alexander Loveday, Director of the Financial and Economic Department of the League, envisaged a general change of direction in economic policy: 'The nutrition campaign changes our whole economic outlook. Ever since the time of Adam Smith, economic thought has centred around the art of production or the conditions of citizens as producers. The nutrition movement reflects the first serious attempt on an international scale, to consider the economics not of production but of consumption. ${ }^{25}$ According to this view, higher standards of living would stimulate economic demand in the industrialized world and thus also help to overcome the economic depression. Food aid was therefore embedded in the larger concept of Keynesianism, advocated by the League and other international organizations under the label of 'economic appeasement' during the 1930s and 1940 s. $^{26}$ It also found broad support among European and North American farmers, who hoped to reduce their surplus production with such a system.

\section{From war to post-war planning: the FAO and Boyd Orr's vision of a global food system}

The debate about international coordination gained momentum during the Second World War, when rationing and food shortages in Europe required massive interventions by the Allies. With the Combined Food Board, established in June 1942 in Washington, DC, a powerful administrative structure was created to coordinate transportation and distribution of staple foods between North America and Europe. ${ }^{27}$ The overall goal was to 'obtain a planned and expeditious utilisation of the food resources of the United Nations'. ${ }^{28}$ Although the Board was formally an institution governed by the United States and Britain, it gradually extended its activities to other countries and regions. While Canada became a formal member of the Board in October 1943, the colonies and dominions of the British empire, as well as of the overseas territories of the other allies, were organized in the London Food

23 League of Nations, Final report of the Mixed Committee on the relation of nutrition to health, agriculture and economic policy, Geneva: League of Nations, 1937.

24 League of Nations, Economic Committee, The agricultural crisis.

25 Cited in Lamartine P. Yates, So bold an aim: ten years of international co-operation toward freedom from want, Rome: FAO, 1955, p. 41.

26 League of Nations, 'Economic appeasement', in League of Nations Official Journal, annex no. 1681, 1937, pp. 1222-9; see also Frank L. McDougall, Food and welfare, Geneva: Geneva Research Centre, 1938; Sean Turnell, 'McDougall: éminence grise of Australian economic diplomacy', Australian Economic History Review, 40, 2000, pp. 51-69.

27 Eric Roll, The Combined Food Board, Stanford, CA: Stanford University Press, 1957.

28 FAO Archives, RG 2, b.1, f.1, 'Note of the meeting to discuss the organization of the Combined Food Board, July 1943, 15th', Appendix B. 
Committee, which was directly associated with the Combined Food Board. From the very beginning, a global approach informed the activities of the new organization. One of the first interventions of the Board dealt with the supply of tea and rice after the Japanese occupation of Java and other countries in Southeast Asia. ${ }^{29}$ In daily meetings, various commodity committees had to devise detailed plans for the distribution of food resources. The allocation of commodities involved both short-term interventions to manage acute deficiencies and more long-term, structural programmes to increase the production of essential foodstuffs and to establish controls over consumption. The Board members agreed that the efforts could not be limited to wartime, since the post-war situation would create new problems relating to food provision. ${ }^{30}$ After the War, the Combined Food Board continued to work until it was replaced by the International Emergency Council of the UN with twenty-one member states. In 1948, all international food agencies created during the War were finally absorbed by the UN Food and Agriculture Organization.

Meanwhile, various other institutions were also engaged in securing food supplies for the civilian populations in the European war zones. In November 1943, the Allies established the United Nations Relief and Rehabilitation Administration (UNRRA) in order to supervise imports into the liberated countries and to build up reserve stocks of food and other consumer products. As Herbert H. Lehman, the later Director-General of UNRRA, pointed out in June 1943, such an operation required an international approach: 'America cannot feed the world from its own resources alone. Neither can Britain nor Russia nor China nor any one of the other American republics. Satisfaction of the wants of the millions of suffering men, women, and children can be accomplished only by the concerted action of all the nations'. ${ }^{31}$ At the same time, numerous religious and philanthropic organizations became engaged in fighting famine in Europe. In 1942, the Oxford Committee for Famine Relief (OXFAM) was founded to supply food to Greece, where thousands of people were starving from hunger while under German occupation. ${ }^{32}$ In November 1945, twenty-two private American organizations initiated the Cooperative for American Remittances to Europe (CARE) to send lifesaving packages to survivors of the Second World War. After the food crisis in Europe ended, both organizations shifted their focus to Southeast Asia and other famine regions in the southern hemisphere.

However, international food aid during the 1940s was not limited to war-related shortages. In 1943, the British government was confronted with the humanitarian crisis in Bengal that took the lives of more than four million people. A preoccupation with the war effort, and the reluctance of the local administration to admit that there was a crisis, turned a massive crop failure into a catastrophe. ${ }^{33}$ The pictures of starving and dying people in Calcutta - 'the empire's second city' - contributed to the massive loss of legitimacy of

29 Paul H. Kratoska, ed., Food supplies and the Japanese occupation in South-East Asia, Basingstoke: Macmillan Press, 1998.

30 FAO Archives, RG 2, b.1, f.1, 'Note of the meeting held at the Ministry of Food to discuss the organization of the Combined Food Board, July 31st, 1943'; 'The future of the Combined Food Board, September 20th, 1943'.

31 Herbert H. Lehman (17 June 1943), in The Department of State Bulletin, S. 539-43.

32 Maggie Black, A cause for our times: Oxfam the first 50 years, Oxford: Oxfam Professional, 1992.

33 Cormac Ó Gráda, Famine: a short history, Princeton, NJ: Princeton University Press 2009, pp. 159-94. 
British colonial rule in India. ${ }^{34}$ At the same time, however, these experiences strengthened claims for a more effective international relief system. Furthermore, food security was tied to the international debate on human and social rights that intensified during the 1940s. ${ }^{35}$ 'Freedom from want' was now defined as the most basic of universal human rights and became a fighting principle of the allies with the Atlantic Charter in 1941.

In the following years, the debate on human rights had a strong impact on the question of whether international food aid should be established permanently and whether there was a moral responsibility for the industrialized nations to fight poverty and hunger worldwide. The humanitarian interventions of the War and post-war era formed the breeding ground for plans to establish an international food system in order to prevent future shortages and famines. The UN Conference on Food and Agriculture, held in Hot Springs, Virginia, in June 1943, had a broad geographic scope, as delegates considered, among other issues, the structural problems of poverty and food insecurity in China and India. ${ }^{36}$ Moreover, the conference was not primarily concerned with short-term humanitarian interventions. Following the traditions of the nutritional movement of the 1930s, the final declaration of the conference framed the problem of hunger in a larger social and economic context:

The first cause of malnutrition and hunger is poverty. It is useless to produce more food unless men and nations provide the markets to absorb it. There must be an expansion of the whole world economy to provide the purchasing power sufficient to maintain an adequate diet for all. With full employment in all countries, enlarged industrial production, the absence of exploitation, an increasing flow of trade within and between countries, an orderly management of domestic and international investment and currencies, and sustained internal and international equilibrium, the food which is produced can be made available to all people. ${ }^{37}$

While most delegates agreed that agriculture would be at the centre of the international post-war economy, both the organizational structure and the functions of the FAO were highly disputed. On the one side, the US - and to some extent also the British - delegation preferred a rather weak structure with primarily consultative and technical responsibilities. They envisioned the FAO as a reincarnation of the IIA founded in 1905 in Rome. Its mandate was to produce global statistical data on food markets, to provide technical advice to national governments, and to give farmers an international voice. ${ }^{38}$ On the other side, the governments of Latin America (especially Argentina and Brazil) and other non-European

34 James Vernon, Hunger: a modern history, Cambridge, MA: The Belknap Press of Harvard University Press, 2007, pp.146-9.

35 Martin H. Geyer, 'Social rights and citizenship during World War II', in Manfred Berg and Martin H. Geyer, eds., Two cultures of rights: Germany and the United States, Cambridge: Cambridge University Press, 2002, pp. 143-66.

36 See e.g. FAO Archives, RG 3, f. 290, 'The problem of China's post-war food supply. Report by the Chinese delegation, May 1943'.

37 FAO Archives, RG 3, f. 233, 'Final Act of the United Nations Conference on Food and Agriculture, Hot Springs, June 3rd, 1943'.

38 Luciano Tosi, 'The League of Nations, the International Institute of Agriculture and the food question', in Marta Petricioli and Donatella Cherubini, eds., For peace in Europe: institutions and civil society between the world wars, Brussels: Peter Lang, 2007, pp. 117-38. 
countries pleaded for a powerful organization able to realize far-reaching regulation of global food markets. They had a strong interest in restructuring international trade in order to regain their former role as food exporters for the industrialized world. Supporters of a strong organization argued that, in the long run, regional famines could not be prevented solely by distributing the surpluses from the industrialized world more efficiently. Instead, agricultural production in the deficit regions had to be increased substantially. This required an overall strategy where short-term aid and long-term economic development went hand in hand. Moreover, in order to secure stable food prices, issues of international trade and market organization had to be considered. ${ }^{39}$

Since the conflicts regarding both the organizational structure and the competences of the FAO could not be resolved, the final declaration of the Hot Springs Conference was somewhat vague. Further decisions were delegated to an Interim Commission that was established in Washington to deal with the open questions. However, the constitution of the FAO, signed by twenty states at the Quebec conference in October 1945, defined only the formal structure of the first permanent UN organization. The precise scope and functions of the FAO remained open, especially regarding the regulation of international markets and trade policy in general. The situation was further complicated by the decision at the Bretton Woods Conference to create an International Trade Organization (ITO) with far-reaching competences in all trade-related issues and economic sectors, including agriculture and the food industries. When John Boyd Orr was appointed first Director-General of the FAO in 1945, he found himself in an ambivalent position. On the one hand, he was faced with the problem that the role of the FAO - as with many other international economic institutions - still had to be defined. In view of the emerging Cold War it was anything but clear whether the concepts of the Bretton Woods Conference would materialize. On the other hand, it was precisely this indeterminacy that provided the leeway for Boyd Orr's vision of a world food system.

The massive food shortages in both Asia and Europe during the post-war years provided further impetus for international initiatives. In much of Southeast Asia, the Japanese occupation had seriously reduced both production and trade of the staple crop, rice, while officials in India had geared production to the needs of the British army and had even ordered the destruction of small fishing boats for fear that they might fall into the hands of the Japanese aggressor. The low production caused by the destruction of farmland and infrastructure in the war-ravaged areas of Europe was worsened by a particularly cold winter. $^{40}$

It was this crisis that seemed to create favourable circumstances for Boyd Orr's farreaching plans that he hoped to realize within a few months. Without consulting the organization's governing bodies, he informed the General Assembly of the United Nations that the FAO would accept the responsibility for mobilizing world resources and convened a

39 For details on the discussions at the Hot Springs Conference, see FAO Archives, RG 3, b. 1-4, United Nations Conference on Food and Agriculture in Hot Springs.

40 Ó Gráda, Famine, pp. 159-94; Ina Zweiniger-Bargielowska, Austerity in Britain: rationing, controls, and consumption 1939-1955, Oxford: Oxford University Press, 2000; Tony Judt, Postwar: a history of Europe since 1945, New York: Penguin Books, 2005, pp. 21-2; Paul H. Kratoska, 'Commercial rice cultivation and the regional economy of Southeastern Asia, 1850-1950', in Nützenadel and Trentmann, Food and globalization, pp. 83-7. 
special meeting on the food crisis in May $1946 .{ }^{41}$ Participants at this conference, who hailed from twenty-one nations, voted that the three-nation Combined Food Board from the War should be replaced by an International Emergency Food Council (IEFC) with a much wider membership. The concept of wartime cooperation between allied countries was thus broadened into a system of worldwide allocation of scarce food resources. The International Emergency Food Council, whose membership was open to any nation represented on one of its sixteen commodity committees, became the only body through which food for export could be purchased. Served by the FAO secretariat, it organized the distribution of supplies to UNRRA and other international relief agencies. ${ }^{42}$

Because the IEFC was intended as only a temporary mechanism, conference participants requested the Director-General of the FAO to develop long-term proposals to deal with the production, distribution, and consumption of food and that were designed to prevent both shortages and surpluses. With characteristic zeal, Boyd Orr responded to the request with an ambitious plan for a World Food Board (WFB), which he presented to the Second Conference of the FAO in September 1946. The plan drew heavily on pre-war studies by the League of Nations and the work of nutritionists such as Stanley Bruce, Frank Boudreau, and Boyd Orr himself, who had been instrumental in creating the FAO.

Indeed, the FAO's World Food Appraisal for 1946-7 estimated a dramatic gap approximately eight to ten million tons - between the required imports of bread grains and the actual supplies on the global market. ${ }^{43}$ Boyd Orr stated that the knowledge and resources existed to expand production vastly but that such a change in the absence of a profound transformation in established patterns of distribution would undermine prices and discourage production in the long run. ${ }^{44}$ In keeping with its mandate to contribute towards an expanding world economy, FAO promoted increased trade, not selfsufficiency. It also warned about a return of widely fluctuating prices for agricultural products and their negative effects on production. In the light of the successful international wartime collaboration, FAO officials believed in the potential of global food market regulation.

As an incentive to maximize production, the WFB aimed to ensure stable prices for agricultural commodities by setting up and operating buffer stocks. Recognizing that underdeveloped countries lacked capital to buy much needed fertilizer, machinery, pesticides, and seeds, the WFB also envisaged a credit facility, which would provide long-term credits and gear its repayment schedule to indices of economic growth in the borrowing country. In addition, the body would also use some of its reserves for famine relief and for concessionary sales to poor countries that could not otherwise meet their food needs.

41 'The Food and Agriculture Organization of the United Nations', International Organization, 1, 2, 1947, pp. 121-3.

42 FAO Report of Special Session, Report of the Conference of FAO - Second Session, Section E VII, http:// www.fao.org/docrep/x5583e/x5583e00.htm\#Contents (consulted 3 December 2010).

43 For a discussion of the World Food Appraisal 1946-7, see Report of the Conference of FAO - Second Session, XII: Report of Commission C to the Conference, http://www.fao.org/docrep/x5583e/x5583e0e. htm\#xii. \%20report \%20of\%20commission \%20c\%20to\%20the\%20conference (consulted 15 June 2010).

44 Proposal for a World Food Board, Washington, DC: FAO Press, 1946. The proposal is discussed in Staples, Birth of development, pp. 85-94; and Shaw, World food security, pp. 15-31. 
Echoing the League of Nations' concept of economic appeasement, the WFB was intended to act as a catalyst for the post-war global economy. Increasing demand would provide farmers with more income to spend and would thus set in motion an upward spiral of prosperity. $^{45}$

The FAO conference approved the WFB in principle and set up a sixteen-member Preparatory Commission to discuss the details of Boyd Orr's proposal or 'any other machinery'. ${ }^{46}$ The Commission's report, however, already foreshadowed the disillusionment with international global food regulation and a return to intergovernmental cooperation. Although the report admitted that global agricultural markets were characterized by severe imbalances and lacked a secure enough food supply for the deficit regions of the southern hemisphere, it favoured bilateral agreements over any kind of world plan. It urged the creation of intergovernmental commodity agreements and focused on different concepts of nationally or regionally operated buffer stocks. Most importantly, it did away with Boyd Orr's vision that there should be a comprehensive regulation of worldwide production and trade within the FAO. ${ }^{47}$

Boyd Orr had argued that the WFB was really nothing new - it merely combined measures that had been taken in different parts of the world into one coherent plan. Considering the positive experiences with wartime planning, the greatly expanded knowledge about the extent of hunger and malnutrition, and the acute food shortage in war-ravaged Europe and Asia, he believed that it was the right time for such an endeavour. Furthermore, there were the precedents of international agreements on other sensitive political questions. The Bretton Woods agreements establishing the International Monetary Fund (IMF) and the International Bank for Reconstruction and Development (IBRD) had just been signed in 1944, and talks leading to the anticipated ITO had begun in the spring of $1946 .^{48}$ The WFB would have stabilized prices for commodities just as the IMF stabilized currencies. Whereas the IBRD was set up to help countries devastated by war to reconstruct their economies, the WFB's lending facility would extend credits to small farmers, who could not otherwise obtain loans from any other lending institution.

However, there were not just internal differences that rendered such wide-ranging concepts unrealistic. More important were the growing international tensions of the Cold War, which impeded all attempts to create a stable international system of economic institutions and rules. When Boyd Orr drew up the WFB in 1946 there were still indications that the Soviet Union intended to join the FAO. ${ }^{49}$ It had been a founding member and an observer in the Conferences of 1945 and 1946. But the Soviet Union's refusal to be part of the preparatory group made it more than doubtful that it would support the scheme. A worldwide plan for agriculture without the participation of the Soviet Union, with its huge grain production, made little sense to contemporaries - although later

\footnotetext{
45 Staples, Birth of development, p. 87.

46 Shaw, World food security, p. 26.

47 Ibid., p. 29.

48 Georg Schild, Bretton Woods and Dumbarton Oaks: American economic and political postwar planning in the summer of 1944, New York: St. Martin's Press, 1995; Bordo and Eichengreen, Retrospective. 
decades would show that the virtual non-participation of the Soviet Union in the 'free' world market did not hurt. ${ }^{50}$

Yet, even without Cold War tensions, it is doubtful whether the US and Great Britain would have agreed to the WFB, which would have taken the control of sensitive areas of agricultural trade and production away from governments. Despite Boyd Orr's claim that the WFB benefited everyone, the British government worried about the ensuing price increase, which would have hurt the UK as a traditional large-scale food importer, and it had only limited trust in the functional abilities of such an international organization. ${ }^{51}$

But it was US opposition that ensured that the WFB would not pass, despite strong support from France, Austria, Poland, Greece, and other food-importing countries. As the largest exporter and with the world's strongest economy, the United States had a veto position in all decisions regarding international trade. Indeed, the US had little to gain from Boyd Orr's WFB, yet it would have had to provide the bulk of the funds for the new institution. ${ }^{52}$ As Norris E. Dodd, then US Under-Secretary of Agriculture, explained early on in the deliberations about the establishment of the WFB in 1946: 'Governments are not likely to place the large funds needed for financing such a plan in the hands of an international agency over whose operations and price policy they would have little or no control. ${ }^{53}$ This did not bode well for the future. In the same year, the US Congress declined to ratify the Charter for the ITO, which included a set of rules and procedures for the conclusion and operation of international commodity agreements.

Despite this setback, Norris E. Dodd, who had become Boyd Orr's successor as Director-General, commissioned his institution to devise new, more restricted, plans for the stabilization of agricultural commodity markets. ${ }^{54}$ The main goal of this initiative was to alleviate the short-term fluctuations of commodity prices on the global market. Even though there was a broad consensus that such stabilization was beneficial for exporters as well as importers, producers as well as consumers, Dodd, like Boyd Orr, had misjudged governments' willingness to render control over commodity policy to an outside organization. Furthermore, it was simply impossible to satisfy the conflicting goals of low consumer prices, high farm incomes, maximized market shares, and increased production in one comprehensive scheme. Furthermore, these schemes would have competed with existing national food aid programmes, which had their own political agendas. ${ }^{55}$ It fits the general picture that none of the recommendations contained in the report on the World Food

50 For the deterioration of US and Soviet relations between 1946 and 1947 see Melvyn P. Leffler, A preponderance of power: national security, the Truman administration, and the Cold War, Stanford, CA: Stanford University Press, 1992, chs. 3 and 4.

51 Sergio Marchisio and Antonietta di Blase, The Food and Agriculture Organization, Dordrecht: M. Nijhoff, 1991, p. 17; Staples, Birth of development, p. 89.

52 Vernon W. Ruttan, United States development assistance policy: the domestic politics of foreign economic aid, Baltimore, MD: Johns Hopkins University Press, 1996, p. 394.

53 British Food Journal, 49, 3, 1947, p. 21.

54 Norris E. Dodd, 'The Food and Agriculture Organization of the United Nations: its history, organization and objectives', Agricultural History, 23, 2, 1949, pp. 81-6.

55 Report of the Conference of FAO - Fifth Session, IV b: International commodity clearing house proposals, http://www.fao.org/docrep/x5579e/x5579e04.

htm\#b.\%20international\%20commodity\%20problems (consulted 3 December 2010). 
Board, or in other expert studies undertaken by FAO staff on food reserves, buffer stocks, or commodity agreements, were passed by the FAO's governing body. ${ }^{56}$ The contrast between the vision of administering worldwide food distribution and the reality, which did not even allow the organization to issue binding rules on food reserves, could hardly be more pronounced.

Despite intense discussions in different fora, comprehensive regulation of trade in agricultural products remained elusive in the coming decades. All attempts in the different General Agreement on Tariffs and Trade (GATT) rounds to create a more liberal market for agricultural products failed. Although reliable prices for both producers and consumers were a major goal of the development community, agreements were almost impossible to reach. Commodity price stabilization was not included among the functions of the GATT until the Uruguay Round, which established the World Trade Organization. Neither was the United Nations Conference on Trade and Development (UNCTAD) successful in establishing comprehensive commodity agreements. ${ }^{57}$ Exceptions were the heavily traded products of wheat, sugar, and coffee, in which special pacts between producer and consumer countries were ratified and extended several times. All of these harked back to pre-war agreements. Of the three, the semi-private international wheat agreement, first signed in 1949, was certainly the most important product for food security. But the 1967 extension failed as a result of separate deals among exporters that aimed to bring the supply situation under control; from that point onwards all economic provisions were suspended. This made all subsequent agreements irrelevant. ${ }^{58}$

\section{Towards a new agenda: international food aid, development, and population}

The worldwide food shortages of the post-war era had provided a 'window of opportunity' for a system of globally managed food supply. However, by the late 1940s, agricultural productivity had recovered to pre-war levels in both Asia and western Europe and exceeded them by a huge margin in the Americas. ${ }^{59}$ Despite the quick recovery, almost all members of the Organisation for European Economic Co-operation (OEEC) opted for making the wartime emergency support measures for agriculture permanent. ${ }^{60}$ Western countries thus

56 Report of group of experts on the establishment of an emergency famine reserve, Rome: FAO, 1953; Functions of a world food reserve: scope and limitations, Rome: FAO, 1956; National food reserve policies in underdeveloped countries, Rome: FAO, 1958.

57 Robert L. Rothstein, Global bargaining: UNCTAD and the quest for a New International Economic Order, Princeton, NJ: Princeton University Press, 1979; Timothy E. Josling, Stefan Tangermann, and T. K. Warley, Agriculture in the GATT, Basingstoke: Macmillan Press 1996.

58 Ronald W. Andersen and Christopher Gilbert, 'Commodity agreements', in Peter Newman et al., eds., New Palgrave Dictionary of Money and Finance, vol. 1, London: Macmillan, 1992, pp. 389-92;

Christopher Gilbert, 'International commodity agreements: design and performance', World Development, 15, 5, 1987, pp. 591-616; History of the International Wheat Agreement, London: International Wheat Council, 1991 (unpublished document).

59 Giovanni Federico, Feeding the world: an economic history of agriculture, 1800-2000, Princeton, NJ: Princeton University Press, 2008, p. 19.

60 Ibid., p. 196. 
concentrated on their own agricultural sector and did not wish for outside interference with their plans.

At the same time, recognition of the global interconnectedness of food markets remained. Growing agricultural surpluses in some parts of the world, coupled with knowledge about the extent of hunger and malnutrition in others, made it unacceptable to let hunger persist. During the 1950s and 1960s, the belief that hunger could be conquered within a decade was genuine and widespread. The development community retained the optimistic zeal of the social scientists of the 1930s and 1940s, as well as their belief in planning, expert knowledge, and technical solutions to complex social problems. On the other hand, within the FAO there was little confidence in the grand design of a global food system. The organization had experienced that it was almost completely dependent on the agendas of national governments. For the foreseeable future at least, this would rule out any major policymaking functions on the part of the organization. Since the early 1950s, most national governments in the OEEC world pursued agricultural policies designed to meet the demands of their respective consumers and producers. Governments in western Europe and the United States subsidized national producers, thus distorting market mechanisms on a global scale, while often at the same time demanding a liberalization of trade regimes. The 'Common Agricultural Policy' of the European Economic Community (EEC), founded in 1957, is only the most notorious example of this trend in the Western world. ${ }^{61}$ Against this background, the FAO lost its position as the sole international organization dedicated to global food issues. Its capacity to influence discourses and practices became limited not only by assertions of national sovereignty but also by new international organizations and NGOs which often openly competed with the FAO. ${ }^{62}$

In order to garner support among its member nations, FAO leadership tried to remain outside political debates during the 1950s and 1960s. FAO's popular Director-General during the 1960s, Binay Ranjan Sen, claimed to have kept 'food out of politics'. ${ }^{63}$ First and foremost this meant giving up all grand ideas of regulating global food markets that were partly absorbed by other institutions such as the UNCTAD.

However, the election of Sen marked a radical change for the FAO. For the first time, the organization was directed by a representative of the 'Third World'. Moreover, the election of the Indian diplomat was also supported by the industrialized countries. Sen could draw on his experience as relief commissioner during the Bengal famine of 1943 and as a director-general of food for all India between 1943 and 1946. He had also been a member of India's first delegation to the UN (1947) and ambassador in different countries, including the US, Italy, and Yugoslavia. Having worked on a variety of FAO projects before his appointment as Director-General, he was convinced that international food aid had to be closely connected to development programmes and other forms of assistance. In 1958, Sen launched an international campaign to encourage farmers to use genetically transformed

61 Rosemary Fennell, The Common Agricultural Policy: continuity and change, Oxford: Oxford University Press, 1997.

62 Shaw, World food security, lists over $100 \mathrm{UN}$ organizations responsible for food security.

63 Binay Ranjan Sen, Towards a newer world: the life of a senior Indian diplomat and former DirectorGeneral of the Food and Agriculture Organization of the United Nations, Dublin: Tycooly, 1982, p. 249. 
varieties of seed for increased production, and soon after merged this with the freedomfrom-hunger initiative. In 1960, he convened a meeting in Rome, attended by various world leaders including eleven Nobel laureates, on the right to freedom from hunger. This was followed up with the first World Food Congress in Washington and a large-scale public relations campaign that targeted private citizens and stressed the themes of empathy with suffering and the common goal of conquering hunger. During his period in office, the FAO completely transformed its role, increasing its budget by almost $350 \%$ and expanding its technical assistance programme.

Nevertheless, Sen was aware that global hunger could only be resolved with an overall strategy aiming at at least three different fields: first, increasing food production in the deficit regions; secondly, controlling the demand for food by curbing population growth; thirdly, distributing surplus food as food aid.

Within the first field, technical assistance became a major part of the FAO's activities. Most agricultural experts agreed that countries in the 'Third World' were lacking technical know-how to help boost agricultural production. Technical aid was politically popular, because it relied on Western expertise, came relatively cheap, and was easy to control. ${ }^{64}$ Its objective was the transfer of know-how from rich to poor countries, particularly by means of the 'expert-counterpart' tandem and, to a lesser degree, by fellowships and training. This is not to say that technical aid and Western knowledge were pressed on the 'developing countries' - quite the contrary. For instance, the UN General Assembly Resolution in December 1948 that led to the creation of the UN Expanded Programme of Technical Assistance (EPTA) was passed at the initiative of Burma, Chile, and Egypt. EPTA's purpose was to arrange for international teams of experts, training abroad, and the building and financing of extension facilities in 'developing countries'. ${ }^{65}$

The majority of EPTA's budget went to agricultural projects, with the FAO receiving around one-third of the total funds. ${ }^{66}$ This rather strong emphasis on agriculture stood in contrast to dominant development doctrines, which tended to stress industrialization as the basis for growth. Until the Green Revolution, which came into full swing only in the 1960s, the two most influential development theories - modernization and dependencia both neglected the agricultural sector. ${ }^{67}$ Modernization theory defined development largely in terms of growth in GDP, and most development economists of the 1950s did not consider agriculture to be an important contributor to economic growth. ${ }^{68}$ The role of agriculture

64 On EPTA, see Olav Stokke, The UN and development: from aid to cooperation, Bloomington, IN: Indiana University Press, 2009, ch. 2; David Owen, 'The United Nations expanded program of technical assistance: a multilateral approach', Annals of the American Academy of Political and Social Science, 32, 3, 1959, pp. 25-32. Examples of the FAO's early field activities can be found in Gove Hambidge, The Story of FAO, New York: D. Van Nostrand Company, 1955, chs. 8-11.

65 Stokke, UN and development, pp. 50-2.

66 The FAO received about $29 \%$ of all funds in the first year of operation (1949) and between one-quarter and one-third of funds between 1950 and 1965 (over these 15 years, US\$128.7 million): see Stokke, UN and development, p. 66, table.

67 William W. Murdoch, The poverty of nations: the political economy of hunger and population, Baltimore, MD: Johns Hopkins University Press, 1980, chs. 5 and 6, discusses a number of hurtful agricultural policies.

68 John M. Staatz and Carl K. Eicher: 'Agricultural development ideas in historical perspective', in John M. Staatz and Carl K. Eicher, eds., International agricultural development, 3rd edn, Baltimore, MD: Johns 
was to support the drive to modernization and to provide the capital to stimulate industrial growth. Surpluses in labour, savings, and expenditures could be siphoned off from a docile agricultural population. ${ }^{69}$ Dependencia, on the other hand, stated that 'underdevelopment' was a condition of impoverishment caused by the integration of low-income economies into the world capitalist system. It prescribed that countries should follow a strategy of import substitution for industrial products. ${ }^{70}$ This strategy not only neglected agriculture in its race to build urban industry, but frequently penalized it. ${ }^{71}$

Considering the relative neglect of agriculture in development theory and practice, it is surprising that agricultural production in 'developing countries' expanded. A large part of production increases in the 'developing world' can be attributed to the spread of new high yielding crops. But despite phenomenal successes, particularly in Asia, the Green Revolution did not end hunger. In fact, it may even have contributed to social injustices, which in the long run hampered agricultural development. ${ }^{72}$ Technical invention thus could neither compensate unsound national agricultural policies nor ameliorate unjust patterns of landownership.

Moreover, increasing production could have only limited effect when demand increased as a consequence of population growth and new consumption patterns. Even though worldwide agricultural production kept pace with or even slightly overtook population growth, at least from the early 1960s, ${ }^{73}$ demography became a major issue in debates on global food policies. Most development experts and also the FAO itself promoted proactive population policies, with the goal of reducing the number of people who needed to be fed.

Hopkins University Press, 1998, pp. 9-10. On the long history of theories of modernization (with an emphasis on sociologists), see Wolfgang Knöbl, Spielräume der Modernisierung: das Ende der Eindentigkeit, Weilerswist: Velbrück Wissenschaft, 2001. Walt W. Rostow, Stages of economic growth: a non-communist manifesto, Cambridge: Cambridge University Press, 1960, was the text that probably influenced policymaking and public opinion most; see Michael E. Latham, Modernization as ideology: American social science and 'nation building' in the Kennedy era, Chapel Hill, NC: University of North Carolina Press, 2000.

69 C. Peter Timmer, 'The agricultural transformation', in Staatz and Eicher, International agricultural development, p. 123.

70 G. Edward Schuh and Antonio Salazar P. Brandao, 'The theory, empirical evidence and debates on agricultural development issues in Latin America', in Lee R. Martin, ed., A survey of agricultural economics literature: agriculture in economic development, 1940s to 1990s, Minneapolis, MN: University of Minnesota Press, 1992, pp. 572-96.

71 John Rapley, Understanding development: theory and practice in the Third World, 3rd edn, Boulder, CO: Lynne Rienner Publishers, 2007, p. 51. See also Lloyd G. Reynolds, Economic growth in the Third World, 1850-1980, New Haven, CT: Yale University Press, 1985, pp. 424-7. The first to describe the urban bias was Michael Lipton, Why poor people stay poor, London: Temple Smith, 1977; see also Staatz and Eicher, 'Agricultural development ideas', p. 13.

72 Francine Frankel, India's Green Revolution: economic gains and political costs, Princeton, NJ: Princeton University Press, 1971; Keith Griffin, The political economy of agrarian change, Cambridge, MA: Harvard University Press, 1974; D. K. Freebairn, 'Did the Green Revolution concentrate incomes? A quantitative study of research reports', World Development, 23, 2, 1995, pp. 265-79. Freebairn reviewed 300 academic studies on the Green Revolution during the period 1970-1989. Over 80\% of these studies concluded that greater inequalities resulted.

73 According to World Trade Organization statistics, agricultural production grew faster than world population. In the period from 1950 to 2000, agricultural production tripled - growing at a median of $2.3 \%$ annually, while world population increased by 2.4 times. 
The FAO was no exception to this overall trajectory. In the short time span from 1959 - when a lecture on birth control by Arnold Toynbee to the FAO Conference had 'caused a storm' of opposition - to the mid 1960s - when its Director-General Binay Ranjan Sen became the first leader of a UN organization publicly to endorse birth control - it became accepted knowledge that without curbing population growth development would not be possible. ${ }^{74}$ Sen was convinced that 'at the present rate of development of population versus resources, uncontrolled famines would develop around 1980'. The FAO did not actively engage in campaigns for birth control because it knew about the sensitivities of its Catholic member states. It did, however, hold several conferences on the integration of rural development and population policy, and advised the governments of Tanzania, Pakistan, and India at their request. ${ }^{75}$ Handbooks for fieldworkers focusing on home economics, who themselves were mainly women, explained how they could integrate the topic of birth control education into their visits to rural homes. ${ }^{76}$ Furthermore, FAO statistics now correlated agricultural production with population growth in the 'developing countries'. 77

Considering that the FAO collected and disseminated statistics on worldwide food consumption, it is quite striking that population control was deemed to be the only solution advocated for the 'demand side problem'. While a senior staff members' statement blaming Western habits of consumption for inequalities in food distribution was widely cited in the press, it was not translated into official policy. ${ }^{78}$ Trying to right this imbalance in consumption remained a private affair, or, as the bestselling cookbook Diet for a small planet advertised, it was about 'changing yourself - and the world - by changing the way you eat'. 79

The third field where the FAO enlarged its activities regarded the distribution of surplus production from the industrialized world. During the interwar period and the Second World War, large relief operations had saved millions of people from starvation. In these emergency operations, food was given away for free. The Marshall Plan marked the beginning of food aid as a tool for development. It served as one model of how concessional sales of food could be used to improve nutrition and stimulate growth in receiving countries. Commodities, supplied by the US to Europe, were allocated directly to individual

74 Sen spoke to the UN Population Commission on 30 March 1965: FAO Archive, RG 8, b. 49, 'Program and Policy Board, Summary Record: Meeting 766, Tuesday, 6 April 1965'.

75 See 'FAO/WHO seminar of food and nutrition problems in Africa, South of Sahara (Belgian Congo, May 1959)', Rome: FAO, 1959; Proceedings of the West African Conference on Nutrition and Child Feeding (Dakar, Senegal, March 1968), Rome: FAO, 1968; 'Report on curriculum development on the population and family life education project, Arusha, Tanzania', Rome: FAO, 1980.

76 'The role of rural women in home economics and nutrition', FAO Nutrition Newsletter, 8, 3, 1970, pp. 33-8; Proceedings of conference on planning a home economics program for community development works (Nairobi 1965), Rome: FAO, 1965.

77 FAO and Unesco, Man and hunger, Rome: FAO, 1959; Peter Collins, Millions still go hungry, Rome: FAO, 1962; Otto Fischnich, The world's food supply: needs - possibilities - prospects up to the year 2000, Rome: FAO, 1967.

78 Sartaj Aziz, 'The world food situation: today and in the year 2000', in Proceedings of the World Food Conference of 1976, Ames, IA: Iowa State University Press, 1977, p. 23.

79 Frances Moore Lappé, Diet for a small planet, New York: Ballantine Books, 1971. It promoted a vegetarian diet with a focus on proteins found in grain/legume combinations. 
governments, which sold the food in exchange for their own local currency through regular market channels. This had the advantage of quickly rehabilitating food marketing systems and released hard currency that would otherwise have had to be spent on food imports. $^{80}$

But the food aid system that emerged in the 1950s and 1960s was increasingly concerned with donor country interests. When the United States first established the Agricultural Trade and Development Act of 1954, its main goals were to relieve the country of costly surpluses and to develop new markets. In the ensuing years, the administration increasingly used its food aid programme, now termed 'Food for Peace', as a political tool. This was done most blatantly under President Johnson, who kept India on a short tether in order to ensure political good behaviour, and under Presidents Johnson and Nixon in South Vietnam, where the local currency generated by the sale of American concessionary aid flowed back to the country in support of the counterinsurgency. ${ }^{81}$ But the programme also entailed a strong element of humanitarian, unconditional aid. Its Title II Program supplied non-governmental organizations with food to be granted in the context of their development and relief programmes.

The US was also instrumental in installing the FAO/UN World Food Programme (WFP), which began operations in 1961 as the only multilateral food aid organization. ${ }^{82}$ In its first decades the WFP was mainly concerned with smaller projects to improve nutrition and with food-for-work schemes. While the organization tried to focus on the needs of recipient countries, it was limited by its reliance on the pledges of donors.

During the course of the Kennedy Round of the GATT, the USA pressed the EEC into accepting a Food Aid Convention (FAC) as part of the international wheat agreement. Since the Europeans refused to ease access restrictions to the common market, the US aimed to ensure that part of the European surpluses were used in food aid operations instead of being dumped on world markets. An equally strong motive was a desire for burden sharing. The US administration felt a responsibility to uphold food aid on at least the existing level, but was unwilling to shoulder the mounting costs. When the Japanese were reluctant to sign the FAC, the US threatened to let the entire Kennedy Round collapse. ${ }^{83}$

All food aid operations were guided by the FAO rules on surplus disposal, which were developed in 1954 and still apply today. The acceptance of the surplus disposal guidelines formally established what seemed to be the outer limits of agricultural commodity coordination that the major food-exporting countries, particularly the United States, were willing to accept. ${ }^{84}$ The main concern of this code of behaviour was the non-interference in regular food markets. Donations had to be in addition to what a country would normally

80 Hans Singer, John Wood, and Tony Jennings, Food aid: the challenge and the opportunity, Oxford: Clarendon Press, 1987, p. 21.

81 Mitchel B. Wallerstein, Food for war, food for peace, Cambridge, MA: MIT Press, 1980; Kirsten Ahlberg, Transplanting the great society: Lyndon Johnson and food for peace, Columbia, MO: University of Missouri Press, 2008.

82 Vernon W. Ruttan, 'The politics of U.S. food aid policy: a historical review', in Vernon W. Ruttan, ed., Why food aid?, Baltimore, MD: Johns Hopkins University Press, 1993, pp. 2-38.

83 National Archives of the United States (NARA), RG 59, Central Foreign Policy Files 1967-1969, AGR 15, Box 427, GATT files.

84 Ruttan, United States development, p. 395. 
buy on regular markets, and competitors had to be informed of all food aid operations beforehand. It was thus a system that was mainly guided by donor country interests in market development and the disposal of surpluses. Although the needs of receiving populations were not central to the food aid system, they did benefit from it in some ways. It certainly ameliorated some food crises and contributed to overall food security. ${ }^{85}$ Although it has been argued that food aid caused 'developing countries' to depend on cereal imports, this simply overrates the importance of food aid operations. ${ }^{86}$ Rather, the increase in cereal imports to the 'Third World' can be explained by unjust trading patterns and the growth in productivity in Western countries. ${ }^{87}$

\section{Conclusion}

The 1930s and 1940s saw the rise of a new model of global food politics. This model was strongly moulded by the experiences of the Great Depression and the two world wars, all of which had brought hunger and malnutrition back to Europe. Whereas until the nineteenth century famines and food shortages had commonly been interpreted as regional Malthusian crises, they were now attributed to global economic disturbances and imbalances. It was, however, the convergence of three distinctive elements that moved food to the centre of international economic debates: first, there were the groundbreaking innovations in food and nutritional sciences. While highly innovative research in plant pathology and genetics created entirely new possibilities for expanding food production - even in countries with unfavourable agricultural conditions - the nutritional debate of the 1930s and 1940s brought physicians, agronomists, and social scientists into an intensive, common dialogue on agricultural development. It was no accident that nutritional experts also played a key role in most international organizations of the War and post-war era. Secondly, Keynesianism and other theories of economic planning formed the breeding ground for the regulation of international food markets. Leading figures of the nutritional movement, such as Boyd Orr, Andre Mayer, and Frank McDougall, shared Keynes' technocratic understanding of economic policy and his optimism towards international coordination. They were confident that the new international order would play a crucial role in eliminating famine and poverty in the world. Thirdly, in the context of the war economy, a set of bureaucratic institutions were created that served as a kind of laboratory for social and economic change. The experiences with the Allied Combined Food Board that encompassed more that $50 \%$ of global food production were instrumental for the ambitious plans to regulate international markets after the end of the war.

However, Boyd Orr's vision of a 'World Food Plan' and similar efforts were almost immediately abandoned in the post-war years. This was partly due to the ambiguities of

85 Singer, Wood, and Jennings, Food aid.

86 Harriet Friedmann, 'The political economy of food: the rise and fall of the postwar international food trade', American Journal of Sociology, supplement, 88, 1982, pp. 248-86; Christopher Barrett, 'Food aid's intended and unintended consequences', Esa Working Paper, 5, 2006; see also www.fao.org/es/esa (consulted 3 December 2010).

87 Paul Bairoch, Economics and world history: myths and paradoxes, Chicago, IL: University of Chicago Press, 1995, pp. 150-8 and passim. 
the Bretton Woods systems, which deferred the regulation of international commodity markets to the GATT process. More than most other economic sectors, agriculture was characterized by a rapid disintegration of international markets. While the US government was engaged in defending the interests of American farmers and using international aid to reduce stocks and surplus production, Europe saw a rising tide of protectionism on the national and - from 1957 - also on the European level. Against this background, the FAO turned out to be a rather weak institution, supported only half-heartedly by most industrial nations. While the FAO lost almost all competences in the field of trade and market organization, international food and development aid came to be organized by other governmental institutions or private donors such as OXFAM or CARE. The post-war years also saw the dissolution of the integrative approach that had informed the nutritional debate of the 1930s and 1940s. The prominent role that food had played in the international economic discussions was now supplanted by the concepts of development and population control.

Ruth Jachertz is a Research Fellow in the research programme 'Globalization as a historical process: global food markets and transnational politics in the twentieth century'.

Alexander Nützenadel is Professor of Social and Economic History at Humboldt University, Berlin. 